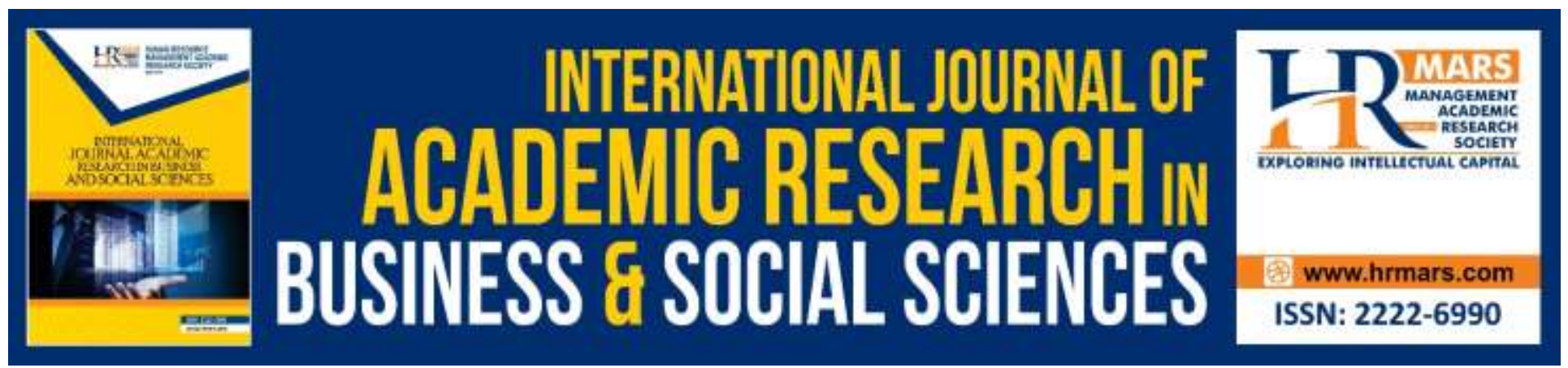

\title{
The Impact of Employees Motivation, Perceived Usefulness and Perceived Ease of Use on Employee Performance among Selected Public Sector Employees
}

Norhayati Omar, Zarina Abdul Munir, Fatin Qaisara Kaizan, Shereen Noranee, Shaherah Abdul Malik

To Link this Article: http://dx.doi.org/10.6007/IJARBSS/v9-i6/6074

DOI: $10.6007 /$ IJARBSS/v9-i6/6074

Received: 13 April 2019, Revised: 07 May 2019, Accepted: 03 June 2019

Published Online: 28 June 2019

In-Text Citation: (Omar, Munir, Kaizan, Noranee, \& Malik, 2019)

To Cite this Article: Omar, N., Munir, Z. A., Kaizan, F. Q., Noranee, S., \& Malik, S. A. (2019). The Impact of Employees Motivation, Perceived Usefulness and Perceived Ease of Use on Employee Performance among Selected Public Sector Employees. International Journal of Academic Research in Business and Social Sciences, 9(6), 1128-1139.

\section{Copyright: (C) 2019 The Author(s)}

Published by Human Resource Management Academic Research Society (www.hrmars.com)

This article is published under the Creative Commons Attribution (CC BY 4.0) license. Anyone may reproduce, distribute, translate and create derivative works of this article (for both commercial and non-commercial purposes), subject to full attribution to the original publication and authors. The full terms of this license may be seen

at: http://creativecommons.org/licences/by/4.0/legalcode

Vol. 9, No. 6, 2019, Pg. $1128-1139$

http://hrmars.com/index.php/pages/detail/IJARBSS

JOURNAL HOMEPAGE

Full Terms \& Conditions of access and use can be found at http://hrmars.com/index.php/pages/detail/publication-ethics 


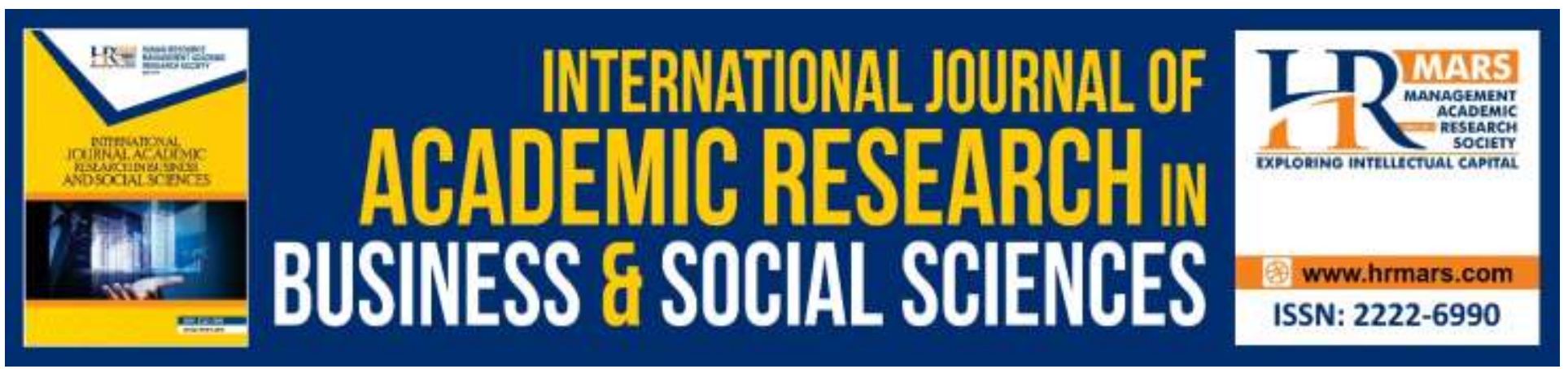

\title{
The Impact of Employees Motivation, Perceived Usefulness and Perceived Ease of Use on Employee Performance among Selected Public Sector Employees
}

\section{Norhayati Omar, Zarina Abdul Munir, Fatin Qaisara Kaizan, Shereen Noranee}

Faculty of Business and Management, Universiti Teknologi MARA, Puncak Alam,Malaysia

\begin{abstract}
Shaherah Abdul Malik
Faculty of Business and Management, Universiti Teknologi MARA, Johor, Malaysia Email: norha981@puncaklam.uitm.edu.my, alifadam1973@gmail.com,sarakhaizan@gmail.com, shahe314@johor.uitm.edu.my, shereen@uitm.edu.my
\end{abstract}

\begin{abstract}
The current study is titled "The Impact of Employee Motivation, Perceived Usefulness and Perceived Ease of Use on Employee Performance among Selected Public Sector Employees". Selected staff from public sector positions were used in order to examine and analyze the factors which contribute to employee performance levels. The independent variables in this case are motivation, perceived usefulness and perceived ease of use. The dependent variable is employee performance. Questionnaires were distributed among 201 respondents who are employed in the public sector. The resulting data was processed through frequency analysis, reliability analysis, descriptive analysis, correlation analysis and regression analysis by using SPSS version 21 . The findings reveal that there exists a positive significant relationship between all the independent variables and the dependent variable, which is employee performance. The Research hypothesis is supported.
\end{abstract}

Keywords: Employee Motivation, Perceived Usefulness, Perceived Ease of Use, Public Sector Employees, Employee Performance

\section{Introduction}

Strong performance management activity is crucial to the process of motivating employees to reach optimal performance levels. Azar and Shafighi (2013) assert that when an employee is motivated, they will put more effort into their tasks and consequently improve their performance. This is due to 
the fact that motivation influences employee performance. Studies by Hawthorne and other researchers reveal the fact that employees who are satisfied at work will display better performance and job retention compared to workers who are dissatisfied with their jobs (Landy, 1985).

In addition, employee performance reflects the belief of the workers regarding their role and behavior towards the organization's accomplishments (Ahmad \& Khurram, 2011). According to Ahmad and Shahzad (2011), actual employee performance is a representation of the employees' attitude regarding how their actions and contributions impact the firm's achievements. The same study also determines that performance evaluation, compensation practices and promotional practices are factors related to or capable of measuring employee performance.

Implementation of technology in the workplace depends on user acceptance and change management, which are important issues to industry practitioners and academics (Baxter, 2014). According to Ndubisi (2005), although users may doubt new technology due to the preconception that they are difficult to use, individuals will eventually develop a more open attitude and intention to learning about and adapting to the new technology. Davis (1989) selected the Technology Acceptance Model (TAM) due to the fact that it is widely used in research within the scope of information systems utilization studies.

Organizations must encourage workers to adopt to the use of new technology and provide incentive for them to improve their job performance (Dauda \& Akingbade, 2011). Regardless of the use of old or new technology, employees who have negative attitudes about work can spread their influence through the organization and result in workers with less commitment and more desire to leave. Dauda and Akingbade (2011) state that through the implementation of technology, individuals can improve productivity and enhance performance along with the use of other available resources, and work towards an efficient and ethical use of technology with the help of the organization.

Additionally, research has proven a positive relationship between employee performance and technology growth, reflecting the important contribution of technology towards workers' performance (Foster, 1989). Aside from this, HR department processes have implemented electronic HR management systems in order to adapt to the new technology used in organizations (Stone \& Dulebohn, 2013), thus prompting the evolution of HR from a necessary but standard component of a firm into a vital and strategic element within the organization (Maier et al., 2013; Hussain et al., 2007).

\section{Literature review \\ Employee Performance}

Kinicki and Kreitner (2007) state that satisfied and happy employees record better performance levels and are more easily motivated to achieve goals. Job performance entails the ability to complete assigned tasks within the established parameters (Aliya, Maiya et al. 2015). Additionally, employees are afforded respect as the main resources of the organization that make daily processes and functioning possible for the firm (Mudah, Rafiki \& Harahap, 2014).

\section{Employee Motivation}

Orpen (1997) asserts that a stronger mentor-mentee relationship in the firm's formal mentoring program can result in more mentees who are motivated and committed to the organization's 
achievements. Individuals naturally seek meaningful connection and purpose in their jobs, and possess desires to foster connections and be included in a community. This makes them feel that their jobs are worth doing and consequently motivates them to aim for success and personal growth (Duchon, 2000). The advancement of technology also has an immediate effect on employee performance (Orpen, 1994). Motivated employees will be dedicated and work hard to solve the most difficult issues faced by the organization (U.S., 2013).

\section{Perceived usefulness}

Davis (1989) highlights how perceived usefulness is defined as the extent to which someone is convinced that using a particular framework would benefit their job performance. Within the TAM framework, perceived usefulness is asserted to be the direct interpreter of an individual's behavior intention with regard to using a particular technological apparatus or procedure (Park, et al., 2014). Existing research points to the connection between perceived usefulness and continuation intention within the context of e-text (Baker-Eveleth \& Stone, 2015; Stone \& Pastry Specialist- Eveleth, 2013), online travel services (Li \& Liu, 2014) e-learning (Lin \& Wang, 2012) blog learning (Tang, Tang, \& Chiang, 2012), instant messaging (Wang, Ngai, \& Wei, 2011), mobile service providers (Abbas \& Hamdy, 2015) and knowledge creation (Chou, Min, Chang, \& Lin, 2009).

\section{Perceived ease of use}

Perceived ease of use is defined by Davis (1989) as the extent to which an individual believes that utilizing a certain piece of technology will demand no effort from them. Perceived ease of use (PEOU) will also have an effect on the individual's attitude towards using a particular piece of technology (Rauniar et al., 2014). However, Lee \& Lehto (2013) compare this to another study which concludes that perceived ease of use had no influence on perceived usefulness. Individuals can understand that a certain technological application is advantageous to them but simultaneously find it inconvenient to use. In this case the technology's beneficial impact does not compensate for the effort needed to utilize that technology.

\section{Motivation and Employee Performance}

In the article titled "Factors Influencing Employees' Performance: A Study on the Islamic Banks in Indonesia" by Linz et al., (2006) it is asserted that employee motivation is a crucial component of an organization's functions. High motivation is reflected in job satisfaction, feelings of fulfillment in one's work, and long-term commitment to the firm which raises productivity and enhances performance. As such, the best results for the organization can be achieved through cultivating strong motivation in workers.

In Asim's (2013) article titled "Impact of Employee Motivation on Employee Performance", a study conducted to discover the impact of employee motivation on work performance was outlined. It is asserted that employees with higher motivation will have higher employee performance as a result. This reveals the relationship between employee performance and motivation, whereby a motivated employee has the intention and drive to work hard and show good results.

Additionally, Azar and Shafighi, (2013) in the article "The Impact of the Motivation on the Employee's Performance in Beverage Industry of Pakistan" state that motivation will induce 
employees of a firm to take their tasks and responsibilities seriously. Motivated employees will make note of the duties and obligations expected of them, and take initiative and effort to accomplish those matters for the benefit of the organization and for their own enhanced job performance

The article titled "The Impact of Motivation on Employees' Job Performance at Prudential Confirmation Malaysia Berhad in Seberang Jaya, Penang", published by Touré-Tilleryand Fishbach (2014) posited that the worker's level of motivation is what determines their performance on assigned tasks based on choice, speed or time taken to complete the work, and task performance. As such, employees require motivation in order to prioritize between speed, choice and task performance in order to improve their work performance.

Lastly in an article titled "Motivation and Rewards to Health Professionals", written by Purohit and Bandyopadhyay (2014), a study conducted in India among doctors revealed that intrinsic factors have a stronger impact on employees compared to extrinsic factors. Such intrinsic factors include respect, acknowledgement and job security. In other words, an employee will have greater motivation levels when they feel appreciated, respected and stable in their position at work. When these needs are fulfilled, they will be motivated and this is reflected in stronger work performance. $\mathrm{H} 1$ : There is a significant relationship between motivation and employee performance.

\section{Perceived Usefulness and Employee Performance}

Davis (1989) through the article "The Effect of Perceived Usefulness and Perceived Ease of Use on Continuance Intention to use E-Government" posits that perceived usefulness refers to the degree to which a person is convinced that utilizing a specific form of technology will strengthen their job performance. In other words, this is the belief that the use of this technology will improve workers' performance over time.

In the paper titled "Technology Acceptance: A Quantitative Study of Texas Nonprofit Sectors", by Carnochan, Samples, Myers, and Austin, (2014) and Hackler Saxton (2007) it is argued that information technology has the capacity to encourage greater internal productivity, support performance assessment, increase the efficiency of nonprofit organizations, and create more avenues for service delivery. In this way, information technology can help an organization be more efficient by helping employees adjust and make use of new technology appropriately and effectively. This results in better performance for the staff and higher productivity for the firm.

Elias, Smith, and Barney (2013) in their article titled "User Acceptance in Baking Automation: An Extension of the Unified Theory of Acceptance and Use Technology (UTAUT) to Manufacturing", highlighted that the attitudes of employees are imperative to the success of the application of new technology in organizations. This is due to the fact that employees learn to adapt to the technology gradually over time. As they grow more comfortable with the technology, they can improve their performance every day.

On the basis of an article titled "User Acceptance of the Human Resource Information System: A Study of a Private Hospital in Malaysia", Winkler et al. (2013) pinpointed the fact that assessment of perceived usefulness was also enhanced through some small changes. In other words, workers will become familiar with technology as the system continues to improve, and consequently the individual's job performance also improves. 
The article titled "The Effect of Perceived Usefulness and Perceived Ease of Use on Continuance Intention to use E-Government", published by Park et al., (2014) with relation to the Technology Acceptance Model (TAM) system, contextualizes perceived usefulness (PU) as a direct indicator of behavioral intention to use (BI) the technology or application in question. This means that if an employee has the behavioral intention to make use of a certain piece of technology, that employee will have the tendency to use the technology continuously. Additionally, there can be a considerable growth in the worker's job performance.

$\mathrm{H} 2$ : There is a significant relationship between perceived usefulness and employee performance.

Perceived Ease of Use and Employee Performance

Rogers (1962), in an article titled "The Role of Perceived Usefulness, Perceived Ease of Use, Security and Privacy and Customer Attitude to Engender Customer Adaptation in The Context of Electronic Banking", explains that perceived ease of use is the extent of the reaction to new technology as being inaccessible, inconvenient or complicated to use. Users may also be convinced than an existing or older form of technology is of better quality than newer versions. If employees can good levels of perceived ease of use, they will have a better time familiarizing themselves to the new technology and subsequently enhancing their job performance.

The paper titled "New Determinants of Ease of Use and Perceived Usefulness for Mobile Banking Adoption", by Rauniar et al., (2014) emphasizes the fact that perceived ease of use influences one's perspective towards utilizing a specific form of technology. If an application or system is easy to use, people will more eager to learn, adapt and eventually develop the intention to use it. Job performance will be improved after a period of sustained and consistent use of the technology.

Guritno and Siringoringo, (2013) in their article "The Influence of Perceived Usefulness and Perceived Ease of Use on the Continuous Intention to Use Electronic Collection System in Nigerian Hospitals: A Conceptual Approach" state that perceived ease of use was a concept created to have an immediate impact on user intention for the process of electronic air-ticketing systems.

The article "Want to Take a Ride with Me?", by Erasmus et al., (2015), explains how research points to a positive link between perceived usefulness and perceived ease of use. A form of technology which is believed to demand less effort in its utilization will be perceived by individuals as being more useful. As such, the existence of a positive relationship between perceived ease of use and perceived usefulness will facilitate better problem solving and execution of tasks by employees. Furthermore, a system of e-Government will result in the use of the Internet to deliver services and information from the government to the people.

In the paper put forth by Lin et al., (2011) it is posited that perceived ease of use had a significant influence on individual's attitudes in choosing to utilize e-Government applications. In other words, the user's age or gender has no consequence on technology use as long as the individual has a positive attitude and perspective regarding the adoption of new and different technology. $\mathrm{H} 3$ : There is a significant relationship between perceived ease of use and employee performance.

The following diagram outlines the theoretical framework which explains the relationships between perceived usefulness, motivation and perceived ease of use towards employee performance among workers in the public sector. This study will examine all the variables which have a possible influence on work performance. 


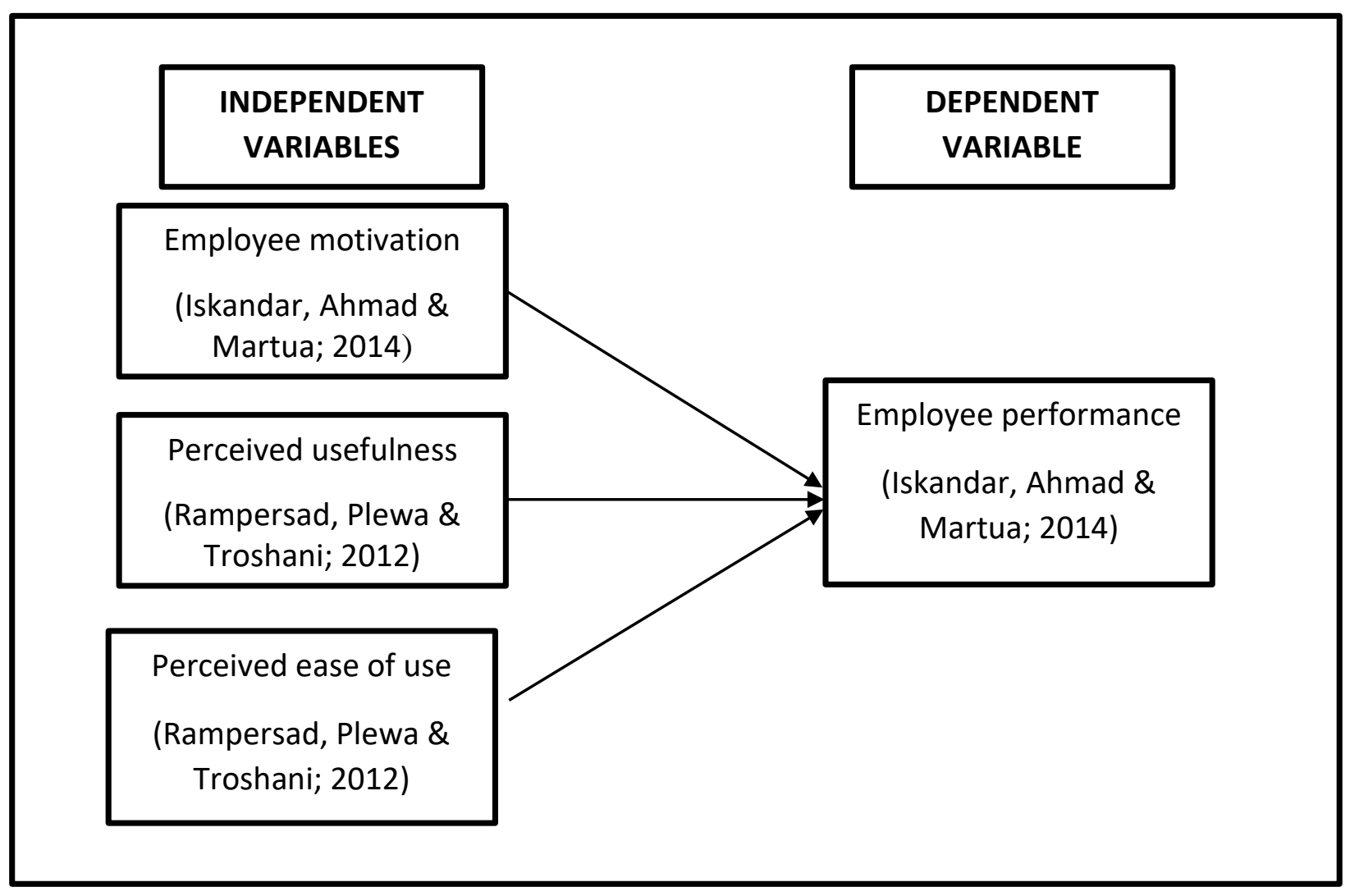

Figure 1: Research Framework

\section{Methodology}

This section will lay out the research design selected for the current study in order to provide information and minimize doubts. The objective of the study was to test the hypotheses between independent and dependent variables. This process is conducted through correlational research in order to investigate the relationships and the significance of these connections between the independent and dependent variables. Correlational research is explained as a form of qualitative study which aims to discover "the way and scale of the relationship among variables through the use of correlational statistics" (Gall et al, 2007, p. 636).

The population of the research involves employees in the public sector, where the total numbers 800 people. The current study used these public sector staff as a sampling frame. There is a tendency to use the biggest possible sample size when using questionnaires. It is essentially an issue of the level of accuracy desired in the results and the degree of the respondents' confidence when answering. Krejcie and Morgan (1970) offer the optimal sample size for a population, whereby a population size $(N)$ of 800 would be ideally represented by a sample size $(S)$ of 201 of mixed gender. As such, 201 sets of questionnaires were distributed among the staff. The reliability of the instrument 
INTERNATIONAL JOURNAL OF ACADEMIC RESEARCH IN BUSINESS AND SOCIAL SCIENCES

Vol. 9, No. 6, June, 2019, E-ISSN: 2222-6990 (C) 2019 HRMARS

was established through Cronbach's Alpha test conducted through the software program Statistical Package for Social Science (SPSS).

\section{Results and Discussion}

\section{Correlations}

\begin{tabular}{|c|c|c|c|c|c|}
\hline & & DV & IV1 & IV2 & IV3 \\
\hline \multirow{5}{*}{ DV } & Pearson & 1 & $.639^{* *}$ & $.530^{* *}$ & $.448^{* *}$ \\
\hline & Correlation & & & & \\
\hline & Sig. (2-tailed) & & .000 & .000 & .000 \\
\hline & $\mathrm{N}$ & 201 & 201 & 201 & 201 \\
\hline & Pearson & $.639^{* *}$ & 1 & $.714^{* *}$ & $.616^{* *}$ \\
\hline \multirow{4}{*}{ IV1 } & Correlation & & & & \\
\hline & Sig. (2-tailed) & .000 & & .000 & .000 \\
\hline & $\mathrm{N}$ & 201 & 201 & 201 & 201 \\
\hline & Pearson & $.530^{* *}$ & $.714^{* *}$ & 1 & $.790^{* *}$ \\
\hline \multirow{5}{*}{ IV2 } & Correlation & & & & \\
\hline & Sig. (2-tailed) & .000 & .000 & & .000 \\
\hline & $\mathrm{N}$ & 201 & 201 & 201 & 201 \\
\hline & Pearson & $.448^{* *}$ & $.616^{* *}$ & $.790^{* *}$ & 1 \\
\hline & Correlation & & & & \\
\hline \multirow{2}{*}{ IV3 } & Sig. (2-tailed) & .000 & .000 & .000 & \\
\hline & $\mathrm{N}$ & 201 & 201 & 201 & 201 \\
\hline
\end{tabular}

**. Correlation is significant at the 0.01 level (2-tailed).

Table 1: Results of Pearson's Correlations

Table 1 exhibits the results of correlational analysis of the significant relationships between the dependent variable, which is employee performance, and the independent variables which are perceived usefulness, motivation and perceived ease of use.

Judging from the above table, the Pearson's Correlation Coefficient for the relationship between employee performance and motivation shows a positively moderate value of correlation ( $\rho$ $=0.639$ ) indicates a notable connection between motivation and employee performance. Despite this, the significant relationship value is at 0.01 .

The next correlation test results show the relationship between employee performance and perceived usefulness. There exists a positively moderate correlation $(\rho=0.530)$ or a notable relationship between employee performance and perceived usefulness. However, the significant relationship value is at 0.01 level.

The next correlation test results reveal the relationship between employee performance and perceived ease of use. There exists a positively moderate correlation value $(\rho=0.448)$ which indicates a notable relationship between employee performance and perceived ease of use. However, it has a significant relationship value recorded at the 0.01 level. 
INTERNATIONAL JOURNAL OF ACADEMIC RESEARCH IN BUSINESS AND SOCIAL SCIENCES

Vol. 9, No. 6, June, 2019, E-ISSN: 2222-6990 @ 2019 HRMARS

Regression analysis is a process which depicts the most ideal estimate of a dependent value based on several independent variables. It helps to establish which of the independent variables are connected to the dependent variable, and examines the nature of these links

Model Summary

\begin{tabular}{|l|r|r|r|r|}
\hline $\begin{array}{l}\text { Mode } \\
1\end{array}$ & R & R Square & $\begin{array}{c}\text { Adjusted R } \\
\text { Square }\end{array}$ & $\begin{array}{c}\text { Std. Error of } \\
\text { the Estimate }\end{array}$ \\
\hline 1 & $.648^{\mathrm{a}}$ & .420 & .411 & .42034 \\
\hline
\end{tabular}

a. Predictors: (Constant), IV3, IV1, IV2

Table 2: Regression Model Summary

Table 2 shows that $R$ value is $0.648, R$ Square is 0.420 and the Adjusted $R$ Square is 0.411 . $R$ Square indicates the percentage variance in the dependent variable that can be explained by the variation in the independent variables namely motivation, perceived usefulness and perceived ease of use. R Square of 0.420 suggests that all the independent variables explained $42 \%$ of the variance in the dependent variable. The remaining $58 \%$ of the variance in the dependent variable is not explained by the independent variables in the current study. This indicates that there are other independent variables which are not included in this study and could further strengthen the regression equation if taken into account.

Coefficients $^{\mathrm{a}}$

\begin{tabular}{|l|r|r|r|r|r|}
\hline Model & \multicolumn{2}{|c|}{$\begin{array}{c}\text { Unstandardized } \\
\text { Coefficients }\end{array}$} & $\begin{array}{c}\text { Standardized } \\
\text { Coefficients }\end{array}$ & \multicolumn{1}{c|}{ S } & \\
\cline { 2 - 4 } & \multicolumn{1}{|c|}{ B } & Std. Error & \multicolumn{1}{c|}{ Beta } & & \\
\hline (Constant & 1.539 & .220 & & 7.002 & .000 \\
) & .543 & .080 & .532 & 6.817 & .000 \\
IV1 & .137 & .092 & .149 & 1.483 & .140 \\
IV2 & .002 & .080 & .002 & .024 & .981 \\
\hline
\end{tabular}

a. Dependent Variable: DV

Table 3: Coefficient of Regression Analysis

Table 3 reveals that the significant, last column (Sig.) of coefficients regression analysis indicates a positive relationship between motivation, perceived usefulness and perceived ease of use with significant values below $5 \%$ or $(0.05)$. The result for the motivation variable is 0.000 which is below the $5 \%$ significant level. Therefore, the motivation variable is considered significant. As such, it can be said that motivation has a positive relationship with employee performance, the dependent variable. This is shown in the very high value of standardized coefficients where Beta $=0.532$. These results show that motivation is a stronger predictor for employee performance compared to the 
other independent variables studied, which are perceived usefulness and perceived ease of use. While motivation has the greatest influence on employee performance, perceived usefulness has the second most significant impact on employee performance followed by perceived ease of use.

\section{Discussions}

Among the participants in the conducted study, a majority of $62.2 \%$ respondents are female, and a majority of $60.7 \%$ of respondents are also single. In terms of race, Malay respondents make up $75.1 \%$ of the demographic. The respondents' education levels show that $36.3 \%$ of them possess a Diploma with working experience between 1 and 3 years. The majority of the respondents also hold supervisor-level positions, and most of them (33.33\%) of them are aged between 18 and 25 years old. This information is relevant due to the fact that the research objectives can best be achieved with a wide demographic of respondents.

Descriptive analysis indicates that the independent variable, employee motivation, registers the highest mean value of 3.7903 with standard deviation of 0.53692 . This could be attributed to the fact that a number of respondents are unhappy to go to work, do not enjoy difficult duties, experience unjust opportunities for career advancement or are generally unsatisfied with their job conditions. Moran (2013) asserts that motivated employees will exhibit passion, enthusiasm and drive to fulfill their tasks. Persistence is also an important quality in employees, which helps them to sustain motivation levels when experiencing challenges and setbacks (Robbins and Judge 2013).

The research questions and objectives in this study were established in order to examine the relationship between the dependent and independent variables. The findings strongly indicate that all independent variables, namely motivation, perceived usefulness and perceived ease of use, have a significant relationship with the dependent variable which is employee performance

\section{Recommendations for Future Research}

This study can serve as a reference or guide for researchers in the future. They may make note of the sections related to problems and results before embarking on new studies. Researchers will also have context regarding topics relevant to their own research questions on the basis of the problems outlined in this study. Aside from this, it is also recommended that future researchers employ a large sample size of respondents. A greater number of respondents can offer more precise data. This helps researchers obtain more relevant and precise results. The data collected from a small sample size also cannot be said to reflect the state of the organization as a whole. Finally, it is recommended that the time period for completing the study be lengthened. When the researcher has more time to conduct their research, there is a better chance of gathering more precise and definitive data and knowledge. The extent of time spent on research is vital to the effective execution and completion of a research study.

\section{References}

Abd. Hamida, A. F. Z. (2016). The Effects of Perceived Usefulness and Perceived Ease of Use on Continuance Intention to Use E-Government. Procedia Economics and Finance, 644-649. 
INTERNATIONAL JOURNAL OF ACADEMIC RESEARCH IN BUSINESS AND SOCIAL SCIENCES

Vol. 9, No. 6, June, 2019, E-ISSN: 2222-6990 @ 2019 HRMARS

Qatmeemalmarhoon, A. B. A. S. K. B. (2011). Effect Of Motivation On Employees' Performance And Employees' Commitment. International Journal of Management and Applied Science, 12091217.

Begum, N. J. (2008). The role of perceived usefulness, perceived ease of use, security and privacy, and customer attitude to engender customer adaptation in the context of electronic banking. African Journal of Business Management, 32-40.

Sekhar, C. M. P. (2013). A literature review on motivation. Global Business Perspectives, 471-487.

Chin Mei Ching, C. W. (2016). The Impact of Motivation on Employees' Job Performance At Prudential Assurance Malaysia Berhad in Seberang Jaya, Penang.

Elnaga, A. I. (2013). The Effect of Training on Employee Performance. European Journal of Business and Management, 2222-2839.

Ervin, J. (2017). User Acceptance of Baking Automation : An Extension of the Unified Theory of Acceptance and Use of Technology ( UTAUT ) to Manufacturing.

Hasan, F. H. (2010). Acceptance of Technological Changes and Job Performance among Administrative Support Personnel in the Government Offices in Maran, Pahang Darul Makmur. Gading Business and Management Journal, 21-32.

Inuwa, M. (2016). Job Satisfaction and Employee Performance: An Empirical Approach. The Millennium University Journal, 90-103.

Shahzadi, I. A. J. (2014). Impact of Employee Motivation on Employee Performance. European Journal of Business and Management, 2222-2839.

Muda, I. A. R. (2014). Factors Influencing Employees' Performance: A Study on the Islamic Banks in Indonesia. International Journal of Business and Social Sience, 73-81.

Kamaludin, K. Z. (2017). User Acceptance of the Human Resource Information System: A Study of a Private Hospital in Malaysia. International Review of Management and Marketing, 207-217.

Hortovanyi, L. A. F. (2015). The impact of ICT on learning on-the-job. The Learning Organization, 213.

Kabir, M. A. S. Z. (2017). A Conceptual Framework on the Influence of Perceived Usefulness, Perceived Ease Use and Computer Self- Efficacy on the Intention To Use Electronic Collection System in Nigerian Federal Hospitals. International Journal of Management Research and Reviews, 259266.

Imran, M. N. M. (2014). Impact of Technological Advancement on Employee Performance in Banking Sector. International Journal of Human Resource Studies, 57.

Nguyen, M. L. (2017). The Impact of Employees Motivation on organizational effectiveness. 51-55.

Isaac, O. Z. A. (2016). Perceived Usefulness, Perceived Ease of Use, PerceivedCompatibility, and Net Benefits: an empirical study of internet usage among employees in Yemen. The 7th International Conference Postgraduate Education (ICPE7), 899-919.

Raza, S. A. A. U. (2017). New determinants of ease of use and perceived usefulness for mobile banking adoption. International Journal of Electronic Customer Relationship Management, 44.

Valle, M. C. (2015). Technology Acceptance: a Quantitative Study of Texas Nonprofit Sectors.

Wahlin, A. F. (2016). Want To Take A Ride With Me? 103.

West, H. V. (2015). The Relationship Between Performance Management and Technology Acceptance Among Government Employees. 
INTERNATIONAL JOURNAL OF ACADEMIC RESEARCH IN BUSINESS AND SOCIAL SCIENCES

Vol. 9, No. 6, June, 2019, E-ISSN: 2222-6990 @ 2019 HRMARS

Thiruselvi S., Y. M. Y. (2013). Continuance Intention Usage Towards E-HRM. Proocedings Book of ICEFMO, Handbook on the Economic, Finance and Management Outlooks, 674-687. 